Jurnal Ners Volume 4 Nomor 1 Tahun 2020 Halaman $35-52$
JURNAL NERS
Research \& Learning in Nursing Science

\title{
FAKTOR-FAKTOR YANG BERHUBUNGAN DENGAN DENGAN PEMBERIAN VITAMIN A PADA BALITA DI POSYANDU DESA BERINGIN LESTARI WILAYAH KERJA PUSKESMAS TAPUNG HILIR 1 KABUPATEN KAMPAR TAHUN 2018
}

\author{
Gusman Virgo \\ Dosen Program Studi Sarjana Keperawatan \\ Universitas Pahlawan Tuanku Tambusai \\ gusmanvirgo@gmail.com
}

\begin{abstract}
Abstrak
Dalam lampiran Peraturan Menteri Kesehatan Nomor 21 Tahun 2015, dinyatakan bahwa untuk mengurangi risiko kesakitan dan kematian pada balita dengan kekurangan Vitamin A, pemerintah menyelenggarakan kegiatan pemberian Vitamin A dalam bentuk kapsul vitamin A biru 100.000 IU bagi bayi usia 6-11 bulan, kapsul vitamin A merah 200.000 IU untuk anak balita usia 12-59 bulan, dan ibu nifas (Kemenkes, 2017). Desa Beringin Lestari berada dibawah target pencapaian yakni hanya 30,60\% untuk pemberian vitamin A warna biru dan 43,10\% dan 69,03\% untuk pemberian vitamin A warna merah. Tujuan penelitian ini adalah untuk menganalisa faktor- faktor yang berhubungan dengan pemberian vitamin A pada balita di posyandu Desa Beringin Lestari wilayah kerja Puskesmas Tapung Hilir 1 Kabupaten Kampar Tahun 2018. Jenis penelitian ini adalah kuantitatif dengan desain cross sectional study. Penelitian dilakukan pada bulan Juli 2018 dengan jumlah sampel 66 orang balita diperoleh dengan menggunakan teknik Systematic Random Sampling. Populasi pada penelitian ini adalah seluruh ibu yang mempunyai balita (6-59 bulan) yang berkunjung ke posyandu Desa Beringin Lestari wilayah kerja Puskesmas Tapung Hilir 1 Kabupaten Kampar pada bulan Januari - Desember tahun 2017. Teknik pengumpulan data kuesioner. Analisa data yang digunakan adalah analisa univariat dan bivariate dengan uji Chi Square. Hasil penelitian didapatkan variabel yang berhubungan dengan pemberian vitamin A pada balita adalah variabel pengetahuan ibu nilai $(\mathrm{p}=0,015)$ dan variabel keaktifan balita dalam berkunjung ke posyandu nilai $(\mathrm{p}=0,000)$. Sedangkan variabel yang tidak berhubungan adalah peran kader nilai $(p=0,203)$. Kesimpulan terdapat hubungan antara pengetahuan ibu dan keaktifan balita dalam berkunjung ke posyandu dengan Pemberian Vitamin A pada Balita di posyandu Desa Beringin Lestari wilayah kerja Puskesmas Tapung Hilir 1 Kabupaten Kampar Tahun 2018. Disarankan diadakan penyuluhan secara berkala mengenai hal-hal yang berhubungan dengan pemberian vitamin A dan meningkatkan peran kader dalam pemberian vitamin A pada balita.
\end{abstract}

Kata kunci: pengetahuan ibu, peran kader, keaktifan balita dalam berkunjung ke posyandu, pemberian vitamin A pada balita

@ Jurnal Ners Prodi Sarjana Keperawatan \& Profesi Ners FIK UP 2020

$\triangle$ Corresponding author :

Address : Jl. Tuanku Tambusai No. 23 Bangkinang

Email : gusmanvirgo@gmail.com

Phone : 085278005288 


\section{PENDAHULUAN}

\section{A. Latar Belakang}

Pertumbuhan dan perkembangan merupakan proses alami yang terjadi dalam kehidupan manusia, dimulai sejak dalam kandungan sampai akhir hayat. Pertumbuhan lebih menitikberatkan pada perubahan fisik yang bersifat kuantitatif, sedangkan perkembangan yang bersifat kualitatif berarti serangkaian perubahan progresif sebagai akibat dari proses kematangan dan pengalaman (Mansur, 2009).

Faktor-faktor yang mempengaruhi pertumbuhan dan perkembangan secara umum ada 2 yaitu faktor genetic dan faktor lingkungan. Faktor lingkungan dibagi menjadi faktor prenatal (pada saat masih dalam kandungan) dan faktor postnatal (anak setelah lahir). Lingkungan postnatal yang mempengaruhi tumbuh kembang anak dapat digolongkan menjadi lingkungan biologis, faktor fisik, faktor psikososial, faktor keluarga dan adat istiadat. Lingkungan biologis antara lain rasa tau suku bangsa, jenis kelamin, umur, gizi, perawatan kesehatan, kepekaan terhadap penyakit, penyakit kronis, fungsi metabolism dan hormon (Adriana, 2011).

Salah satu komponen yang penting dalam pertumbuhan adalah vitamin $A$. Vitamin A adalah vitamin larut lemak yang pertama ditemukan, secara luas, vitamin A merupakan nama generik yang menyatakan semua retinoid dan prekursor atau provitamin A atau karotenoid yang mempunyai aktivitas biologik sebagai retinol. Vitamin A adalah zat gizi yang paling esensial, hal itu dikarenakan konsumsi makanan kita belum mencukupi dan masih rendah sehingga harus dipenuhi dari luar (Almatsier, 2009). Vitamin A adalah salah satu zat gizi penting yang larut dalam lemak, disimpan dalam hati, dan tidak dapat diproduksi oleh tubuh sehingga harus dipenuhi dari luar tubuh (Profil Dinas Kesehatan Provinsi Riau, 2015).

Manfaat vitamin A diantaranya meningkatkan daya tahan tubuh terhadap penyakit dan infeksi seperti campak dan diare, (2) membantu proses penglihatan dalam adaptasi terang ke tempat yang gelap, (3) mencegah kelainan pada sel-sel epitel termasuk selaput lendir mata, (4) mencegah terjadinya proses metaplasi selsel epitel sehingga kelenjar tidak memproduksi cairan yang dapat menyebabkan kekeringan mata, (5) mencegah terjadinya kerusakan mata hingga kebutaan, dan (6) vitamin A esensial untuk membantu proses pertumbuhan (Profil Dinas Kesehatan Provinsi Riau, 2015).

Kekurangan vitamin A (KVA) akan meningkatkan kesakitan dan kematian, mudah terserang penyakit infeksi seperti diare, radang paru-paru, pneumonia, dan akhirnya kematian. Akibat lain yang paling serius dari kekurangan vitamin A (KVA) adalah rabun senja yaitu bentuk lain dari xeropthalmia termasuk kerusakan kornea mata dan kebutaan. Vitamin A bermanfaat untuk menurunkan angka kesakitan angka kematian, karena vitamin A dapat meningkatkan daya tahan tubuh terhadap penyakit infeksi seperti campak, diare, dan ISPA (Infeksi Saluran Pernapasan Akut) (Almatsier, 2009).

Kekurangan Vitamin A (KVA) dapat menurunkan sistem kekebalan tubuh balita 
serta meningkatkan risiko kesakitan dan kematian. Kekurangan Vitamin A juga merupakan penyebab utama kebutaan pada anak yang dapat dicegah (Kemenkes, 2017).

Dalam lampiran Peraturan Menteri Kesehatan Nomor 21 Tahun 2015, dinyatakan bahwa untuk mengurangi risiko kesakitan dan kematian pada balita dengan kekurangan Vitamin A, pemerintah menyelenggarakan kegiatan pemberian Vitamin A dalam bentuk kapsul vitamin A biru 100.000 IU bagi bayi usia enam sampai dengan sebelas bulan, kapsul vitamin A merah 200.000 IU untuk anak balita usia dua belas sampai dengan lima puluh sembilan bulan, dan ibu nifas (Kemenkes, 2017).

Suplementasi kapsul vitamin A pada balita usia 6-59 bulan bertujuan tidak hanya untuk mencegah kebutaan tetapi juga untuk penanggulangan Kurang Vitamin A (KVA) yaitu suatu kondisi dimana simpanan vitamin A dalam tubuh berkurang, akan berdampak kelainan pada mata yang umumnya terjadi pada anak usia 6 bulan sampai dengan 4 tahun yang menjadi penyebab utama kebutaan. KVA biasa terjadi pada anak yang menderita kurang energi protein atau gizi buruk tetapi dapat juga terjadi karena gangguan penyerapan pada usus. Tahap awal KVA ditandai dengan gejala rabun senja atau kurang jelas melihat pada malam hari atau menurunnya kadar serum retinol dalam darah. Selanjutnya terdapat kelainan jaringan epitel pada paruparu, usus, kulit, dan mata (Profil Dinas Kesehatan Provinsi Riau, 2015).

Menurut Panduan Manajemen Suplementasi Vitamin A, pemberian suplementasi Vitamin A diberikan kepada seluruh balita umur 6-59 bulan secara serentak melalui posyandu yaitu; bulan Februari atau Agustus pada bayi umur 6-11 bulan serta bulan Februari dan Agustus pada anak balita 12-59 bulan (Kemenkes, 2017).

Kapsul vitamin A diberikan setahun dua kali pada bulan Februari dan Agustus, sejak anak berumur enam bulan. Kapsul merah (dosis 100.000 IU) diberikan untuk bayi umur 6-11 bulan dan kapsul biru (dosis 200.000 IU) untuk anak umur 12-59 bulan (Kemenkes, 2013).

Sekitar 125 juta balita di dunia mengalami kekurangan vitamin A subklinis, sementara 1,3 juta dari jumlah itu telah menampakkan tanda klinis xeroftalmia. Itu berarti bahwa risiko mereka untuk terjangkit infeksi membesar sebanyak 20 kali.

Angka kebutaan di Indonesia tertinggi di kawasan Asia Tenggara. Berdasarkan Survei Kesehatan Indera Penglihatan dan Pendengaran tahun 2000-2013 menunjukkan angka kebutaan di Indonesia $20 \%$ dari jumlah penduduk atau setara dengan tiga juta orang. Jumlah ini jauh lebih tinggi dibandingkan Bangladesh, Barbados, Paraguay (10,28\%), Tibet (18\%), dan Beijing (13\%) (Kemenkes, 2013).

Upaya-upaya pencegahan kebutaan di Indonesia telah dilaksanakan pada tahun 1967 ketika kebutaan dinyatakan sebagai bencana Nasional sejak 1984 Upaya Kesehatan Mata/Pencegahan Kebutaan (UKM/PK) sudah diintegrasikan ke dalam kegiatan pokok Puskesmas. Sedangkan Program penanggulangan Kebutaan Katarak Paripurna (PKKP) dimulai sejak 1987 baik Rumah Sakit 
(RS) maupun Balai Kesehatan Mata Masyarakat (BKMM) (Kemenkes, 2013)

Hasil Pemantauan Status Gizi 2016, persentase balita 6-59 bulan di Indonesia yang mendapatkan vitamin A sebesar 90,1\% lebih tinggi dari target nasional sebesar $82 \%$. Cakupan pemberian Vitamin A pada balita $6-59$ bulan tertinggi yaitu Provinsi Gorontalo sebesar 95,0\% dan terendah di Papua sebesar 75,3\%. Persentase balita 6-11 bulan mendapat kapsul vitamin A sebesar 69,1\% sedangkan pada balita 12-59 bulan sebesar 93,2\% (Kemenkes, 2017).

Besarnya cakupan vitamin A antara lain disebabkan kondisi geografis dan keterjangkauan akses menuju lokasi posyandu dalam pendistribusian vitamin A. Provinsi yang memiliki cakupan vitamin A yang tinggi, cakupan

Tabel 1.1. CAKUPAN PEMBERIAN VITAMIN A DI PUSKESMAS SE-KABUPATEN KAMPAR TAHUN 2017

\begin{tabular}{|c|c|c|c|c|c|}
\hline \multirow[b]{3}{*}{ No } & \multirow[b]{3}{*}{ Nama Puskesmas } & \multicolumn{4}{|c|}{ Cakupan Pemberian Vitamin A (\%) } \\
\hline & & \multicolumn{2}{|c|}{ 6-11 bulan } & \multicolumn{2}{|c|}{ 12-59 Bulan } \\
\hline & & Februari & Agustus & Februari & Agustus \\
\hline 1 & BANGKINANG KOTA & 91,21 & 91,21 & 89,83 & 89,83 \\
\hline 2 & KAMPAR & 100 & 97,49 & 74,27 & 74,02 \\
\hline 3 & TAMBANG & 97,94 & 95,41 & 92,83 & 90,72 \\
\hline 4 & XIII KOTO KAMPAR I & 86,52 & 92,47 & 88,61 & 87,15 \\
\hline 5 & XIII KOTO KAMPAR II & 93,85 & 89,23 & 98,20 & 94,97 \\
\hline 6 & XIII KOTO KAMPAR III & 98,72 & 96,51 & 88,98 & 89,83 \\
\hline 7 & KUOK & 97,84 & 98,20 & 94,96 & 95,04 \\
\hline 8 & SIAK HULU I & 79,29 & 88,89 & 80,05 & 88,44 \\
\hline 9 & SIAK HULU II & 100 & 100 & 91,47 & 91,88 \\
\hline 10 & SIAK HULU III & 100 & 100 & 98,04 & 88,03 \\
\hline 11 & KAMPAR KIRI & 94,67 & 100 & 91,52 & 93,05 \\
\hline 12 & KAMPAR KIRI HILIR & 75,69 & 100 & 97,12 & 97,30 \\
\hline 13 & KAMPAR KIRI HULU I & 94,78 & 100 & 100,18 & 100 \\
\hline 14 & KAMPAR KIRI HULU II & 97,12 & 88,00 & 97,44 & 96,81 \\
\hline 15 & TAPUNG I & 89,40 & 95,87 & 45,59 & 42,72 \\
\hline 16 & TAPUNG II & 91,58 & 87,06 & 91,01 & 88,69 \\
\hline 17 & TAPUNG & 95,24 & 98,56 & 96,77 & 96,91 \\
\hline 18 & TAPUNG HILIR I & 98,87 & 81,17 & 97,26 & 98,42 \\
\hline
\end{tabular}

penimbangan balita di posyandu nya juga tinggi. Begitu pula sebaliknya, provinsi yang memiliki cakupan vitamin A yang rendah seperti Papua dan Papua Barat disebabkan oleh tingkat partisipasi masyarakat dalam penimbangan balita di posyandu (D/S) juga rendah karena kendala geografis (Profil Dinas Kesehatan Provinsi Riau, 2015).

Cakupan pemberian kapsul vitamin A pada balita (6-59 bulan) di Provinsi Riau tahun 2015 sebesar 81,2\% dimana Kabupaten Kepulauan Meranti menempati peringkat pertama dalam hal pencapaian yakni 95,3\%, diikuti oleh Kabupaten Rokan Hulu (94,7\%) dan Kota Dumai (92,1\%). Kabupaten Pelalawan menjadi yang terendah dengan pencapaian $63,2 \%$ (Profil Dinas Kesehatan Provinsi Riau, 2015). 


\begin{tabular}{rlcccc}
\hline 19 & TAPUNG HILIR II & 95,02 & 94,61 & 83,69 & 88,88 \\
20 & TAPUNG HULU I & 91,53 & 95,24 & 92,74 & 92,74 \\
21 & TAPUNG HULU II & 98,37 & 90,23 & 99,35 & 99,35 \\
22 & SALO & 96,76 & 97,15 & 83,82 & 89,23 \\
23 & RUMBIO JAYA & 94,81 & 89,83 & 92,67 & 91,98 \\
24 & BANGKINANG & 98,37 & 91,37 & 95,21 & 93,67 \\
25 & PERHENTIAN RAJA & 96,76 & 96,24 & 97,40 & 92,19 \\
26 & KAMPAR TIMUR & 94,81 & 87,04 & 85,09 & 84,73 \\
27 & KAMPAR UTARA & 100 & 100 & 96,66 & 91,34 \\
28 & KAMPAR KIRI TENGAH & 93,02 & 100 & 92,72 & 95,66 \\
29 & GUNUNG SAHILAN I & 88,79 & 87,85 & 82,94 & 84,07 \\
30 & GUNUNG SAHILAN II & 101,99 & 100 & 121,23 & 100 \\
31 & KOTO KAMPAR HULU & 91,94 & 91,94 & 92,54 & 92,71 \\
\hline
\end{tabular}

Sumber: Dinas Kesehatan Kabupaten Kampar

Berdasarkan tabel 1.1 puskesmas dengan cakupan pemberian vitamin A terendah pada balita usia 12-59 bulan terdapat pada Puskesmas Tapung 1 yaitu $45,59 \%$ dan 42,72\%. Puskesmas Tapung Hilir 1 sudah mencapai target yakni $81,17 \%$ (balita usia 6-11 bulan) dan $98,42 \%$ (balita usia 12-59 bulan).

Tabel 1.2. Cakupan Pemberian Vitamin A pada Balita di wilayah kerja Puskesmas Tapung Hilir 1 Kabupaten Kampar Tahun 2017

\begin{tabular}{lllcc}
\hline No & Nama Desa & \multicolumn{3}{c}{ Cakupan Pemberian Vitamin A } \\
\cline { 3 - 5 } & & \multicolumn{2}{c}{ Biru } & \multicolumn{2}{c}{ Merah } \\
\cline { 3 - 5 } & & \multicolumn{2}{c}{ Februari-Agustus } \\
$(\mathbf{\%})$ & 114,04 & 80,88 \\
$(\boldsymbol{\%})$ & $\begin{array}{c}\text { Agustus } \\
(\boldsymbol{\%})\end{array}$ \\
\hline 1. & Kota Garo & 84,34 & 109,58 & 92,49 \\
2. & Kota Baru & 104,25 & 102,7 & 113,4 \\
3. & Suka Maju & 99,06 & 80,68 & 64,71 \\
4. & Kota Bangun & 60,95 & 108,51 & 64,14 \\
5. & Cinta Damai & 92,42 & $\mathbf{4 3 , 1 0}$ & $\mathbf{6 9 , 0 3}$ \\
6. & Beringin Lestari & $\mathbf{3 0 , 6 0}$ & 133,30 & 137,37 \\
7. & Koto Aman & 131,31 & & \\
\hline
\end{tabular}

Sumber : Puskesmas Tapung Hilir 1

Berdasarkan Tabel 1.1 dapat dilihat bahwa Desa Beringin Lestari berada dibawah target pencapaian yakni hanya $30,60 \%$ untuk pemberian vitamin A warna biru dan $43,10 \%$ dan $69,03 \%$ untuk pemberian vitamin A warna merah.

Berdasarkan survey pendahuluan yang dilakukan kepada 10 orang ibu yang memiliki balita melalui wawancara
Berdasarkan data yang diperoleh dari Puskesmas Tapung Hilir 1 Kecamatan Tapung Hilir Kabupaten Kampar cakupan vitamin A biru untuk bayi 6-11 bulan mencapai $81 \%$, sedangkan untuk balita mencapai $98,42 \%$. diperoeh hasil 6 orang ibu balita merupakan pekerja, dan 4 orang ibu balita sebagai ibu rumah tangga. 6 orang ibu mempunyai pengetahuan yang kurang baik tentang vitamin A, dan 4 orang ibu balita mempunyai pengetahuan yang baik tentang vitamin A. Diketahui juga $90 \%$ ibu tau tentang vitamin A, 60\% ibu tau tentang kekurangan vitamin A dan $80 \%$ ibu 
tau tentang jadwal pemberian vitamin A. Salah satu kemungkinan penyebab kurangnya pengetahuan ibu balita merupakan salah satu faktor pendorong yang mungkin menyebabkan kurangnya partisipasi ibu untuk memberikan kapsul vitamin A untuk balita dan kurangnya informasi yang didapat oleh ibu balita tentang manfaat pemberian kapsul vitamin A untuk balita. Adanya pengaruh sosial budaya di dalam masyarakat dapat juga mempengaruhi dalam pemberian kapsul vitamin A kepada balita. Peran kader sangat penting dimana kader dapat memberikan penyuluhan tentang pentingnya vitamin $\mathrm{A}$ dan mengingatkan jadwal pemberian vitamin A pada balita.

Berdasarkan penelitian Indarwati (2015) menunjukkan adanya hubungan antara tingkat pengetahuan ibu dengan cakupan pemberian vitamin A pada balita ( $p$ value $=$ 0,024) di PKD Melati Sari Desa Durensari Kecamatan Bagelen Kabupaten Purworejo.

Berdasarkan uraian latar belakang di atas maka penulis tertarik untuk melakukan penelitian mengetahui faktor- faktor yang berhubungan dengan pemberian vitamin A pada balita di posyandu Desa Beringin Lestari wilayah kerja Puskesmas Tapung Hilir 1 Kabupaten Kampar Tahun 2018.

\section{B. Rumusan Masalah}

Berdasarkan uraian dalam latar belakang masalah di atas, dapat dirumuskan pertanyaan penelitian sebagai berikut apakah terdapat hubungan faktor pengetahuan ibu, peran kader, keaktifan kunjungan balita ke posyandu dengan pemberian vitamin A pada balita di posyandu Desa Beringin Lestari wilayah kerja Puskesmas Tapung Hilir 1 Kabupaten Kampar Tahun 2018 ?

\section{Tujuan Penelitian}

\section{Tujuan Umum}

Menganalisa faktor- faktor yang berhubungan dengan pemberian vitamin A pada balita di posyandu Desa Beringin Lestari wilayah kerja Puskesmas Tapung Hilir 1 Kabupaten Kampar Tahun 2018.

\section{Tujuan Khusus}

a. Untuk mengetahui distribusi frekuensi pengetahuan ibu, peran kader, dan keaktifan kunjungan balita ke posyandu di posyandu Desa Beringin Lestari wilayah kerja Puskesmas Tapung Hilir 1 Kabupaten Kampar Tahun 2018.

b. Untuk mengetahui hubungan faktor pengetahuan ibu dengan pemberian vitamin A pada balita di posyandu Desa Beringin Lestari wilayah kerja Puskesmas Tapung Hilir 1 Kabupaten Kampar Tahun 2018.

c. Untuk mengetahui hubungan faktor peran kader dengan pemberian vitamin A pada balita di posyandu Desa Beringin Lestari wilayah kerja Puskesmas Tapung Hilir 1 Kabupaten Kampar Tahun 2018

d. Untuk mengetahui hubungan faktor keaktifan kunjungan balita ke posyandu dengan pemberian vitamin A pada balita di posyandu Desa Beringin Lestari wilayah kerja Puskesmas Tapung Hilir 1 Kabupaten Kampar Tahun 2018.

\section{Manfaat Penelitian}

\section{Manfaat Teoritis}

a. Bagi Peneliti

Diharapkan peneliti dapat menerapkan ilmu pengetahuan yang didapat selama mengikuti perkuliahan serta menambah pengalaman dalam melakukan penelitian. 
b. Bagi Instititusi Pendidikan

Memberi sumbangan pemikiran dan bahan dalam kajian ilmiah mengenai upaya kesehatan masyarakat.

c. Bagi Instansi Tempat Penelitian

Dapat menjadi bahan masukan dan sumber informasi dalam menyusun kebijakan yang akan dilakukan sebagai upaya untuk meningkatkan cakupan pemberian vitamin A pada balita.

2. Manfaat Praktis

a. Hasil penelitian ini diharapkan dapat memberikan perbaikan kebijakan dalam mempengaruhi hubungan faktor pengetahuan ibu, peran kader, keaktifan kunjungan balita ke posyandu dengan pemberian vitamin A pada balita di posyandu Desa Beringin Lestari wilayah kerja Puskesmas Tapung Hilir 1 Kabupaten Kampar Tahun 2018

\section{METODE PENELITIAN}

\section{A. Desain Penelitian}

Jenis penelitian ini menggunakan Desain Penelitian Analitik dengan rancangan Cross Sectional, karena pengukuran variable bebas (pengetahuan ibu, peran kader dan keaktifan kunjungan balita ke posyandu) dengan variable terikat (pemberian vitamin A pada balita) dilakukan pada saat yang bersamaan.

\section{B. Lokasi dan Waktu Penelitian}

1. Lokasi

Penelitian ini dilaksanakan di Desa Beringin Lestari wilayah kerja Puskesmas Tapung Hilir 1 Kabupaten Kampar.

2. Waktu

Penelitian dilaksanakan pada tanggal 09-13 Juli tahun 2018.

\section{Populasi dan Sampel}

1. Populasi

Populasi dalam penelitian ini adalah seluruh ibu yang mempunyai balita (6-59 bulan) yang berkunjung ke posyandu Desa Beringin Lestari wilayah kerja Puskesmas Tapung Hilir 1 Kabupaten Kampar pada bulan Januari - Desember tahun 2017 yang telah diperiksa sebanyak 197 orang balita.

2. Sampel

Sampel adalah sebahagian ibu yang mempunyai balita (6-59 bulan) yang berkunjung ke posyandu Desa Beringin Lestari wilayah kerja Puskesmas Tapung Hilir 1 Kabupaten Kampar. Untuk menentukan besar sampel pada penelitian ini dihitung dengan menggunakan rumus Slovin (Notoatmodjo, 2010) sebagai berikut:

$$
n=\frac{N}{1+N(d)^{2}}
$$

ket : $\mathrm{n}=$ Besar sampel

$\mathrm{N}=$ Besar populasi

$\mathrm{d}=$ Tingkat kepercayaaan/ketepatan

$$
\text { yang diinginkan }=10 \%
$$

$$
\begin{aligned}
n= & \frac{N}{1+N(d)^{2}} \\
= & \frac{197}{1+197(0,1)^{2}} \\
& =\frac{197}{1+197(0,01)} \\
& =\frac{197}{1+1,97} \\
& =\frac{197}{2,97}
\end{aligned}
$$

$$
=66,33
$$

Dari perhitungan di atas, dapat diperoleh jumlah sampel dalam penelitian ini yaitu sebanyak 66 orang. 
Dengan kriteria sampel

1. Kriteria sampel :

a. Kriteria Inklusi

1) Orang tua yang mempunyai balita (6-59 bulan) yang datang berobat ke posyandu Desa Beringin Lestari wilayah kerja Puskesmas Tapung Hilir 1 Kabupaten Kampar

2) Memiliki KMS

b. Kriteria Ekslusi

1) Orang tua yang mempunyai balita (6-59 bulan) yang datang berobat ke posyandu Desa Beringin Lestari wilayah kerja Puskesmas Tapung Hilir 1 Kabupaten Kampar yang tidak bersedia menjadi responden.

a. Teknik sampel

Teknik sampel adalah merupakan teknik pengumpulan sampel dalam melakukan penelitian. Pada penelitian ini teknik sampel yang peneliti terapkan adalah Systematic Random Sampling, yaitu pengambilan sampel yang dilakukan secara acak (Hidayat, 2008).

Dengan menggunakan kelipatan interval sampel yang di tentukan berdasarkan hasil pembagian jumlah populasi dengan sampel (dengan kelipatan 3). Di mana penderita pertama dengan nomor urut 8 yang di pilih secara acak, sedangkan sampel berikutnya di pilih secara sistematik menurut kelipatan tiga sampai jumlah sampel mencapai 66 balita.

b. Jumlah sampel

Jumlah sampel pada penelitian ini adalah sebanyak 66 orang.

\section{Etika Penelitian}

Masalah etika penelitian merupakan masalah yang sangat penting dalam penelitian, mengingat penelitian keperawatan berhubungan langsung dengan manusia, maka segi etika penelitian harus diperhatikan. Masalah etika yang harus diperhatikan antara lain adalah sebagai berikut :

1. Lembar persetujuan menjadi responden

Lembar persetujuan diberikan kepada subjek yang akan diteliti. Peneliti menjelaskan maksud dan tujuan riset yang akan dilakukan serta dampak yang mungkin terjadi selama dan sesudah pengumpulan data. Jika responden bersedia diteliti, maka mereka harus menandatangani lembar persetujuan tersebut, jika responden menolak untuk diteliti, maka peneliti tidak akan memaksa dan tetap menghormati hak-haknya.

2. Tanpa Nama (Anominity)

Untuk menjaga kerahasiaan identitas subjek, peneliti tidak akan mencantumkan nama subjek pada lembaran pengumpulan data, cukup dengan memberikan kode pada masing-masing lembar riset.

3. Kerahasiaan (Confidentiality)

Kerahasiaan informasi yang diberikan oleh subjek dijamin oleh peneliti.

\section{Alat pengumpulan Data}


Instrumen yang digunakan dalam penelitian ini adalah kuesioner sebagai alat pengumpulan data. Pengetahuan ibu, peran kader dan keaktifan kunjungan balita ke posyandu dilihat berdasarkan jawaban pada kuesioner sedangkan pemberian vitamin A dilihat berdasarkan rekam medik di posyandu Desa Beringin Lestari wilayah kerja Puskesmas Tapung Hilir 1 Kabupaten Kampar.

\section{Prosedur Pengumpulan Data}

Dalam melakukan penelitian ini peneliti mengumpulkan data dengan melalui prosedu rsebagai berikut :

1. Mengajukan surat permohonan izin kepada Institusi Universitas Tuanku Tambusai Riau untuk mengadakan penelitian di Puskesmas Tapung Hilir 1.

2. Meminta izin kepada kepala Puskesmas Tapung Hilir 1.

3. Menentukan responden sesuai dengan jumlah sampel yang telah direncanakan.
4. Mendatangi responden sesuai kriteria penelitian untuk pengisian kuesioner.

5. Melakukan sesuai permohonan dijamin kerahasiaannya.

6. Meminta responden untuk menandatangani lembar persetujuan menjadi responden.

7. Membagi lembaran kuesioner sambil menjelaskan cara pengisian.

8. Setelah kuesioner diisi, peneliti langsung mengumpulkan untuk memeriksa kelengkapannya.

9. Apabila belum lengkap responden diminta untuk melengkapinya saat itu juga.

\section{Defenisi Operasional}

Definisi operasional adalah mendefinisikan variable secara operasional berdasarkan karakterisrik yang diamati, memungkinkan peneliti untuk melakukan observasi atau pengukuran secara cermat terhadap suatu objek atau fenomena (Hidayat , 2008).

\section{Tabel 3.1 Defenisi Operasional}

\begin{tabular}{|c|c|c|c|c|c|}
\hline NO & Variabel & $\begin{array}{c}\text { Defenisi } \\
\text { Operasional }\end{array}$ & Alat Ukur & $\begin{array}{l}\text { Skala } \\
\text { Ukur }\end{array}$ & Hasil Ukur \\
\hline \multirow[t]{5}{*}{1} & $\begin{array}{c}\text { Variabel Independen. } \\
\text { Faktor yang } \\
\text { berhubungan dengan } \\
\text { pemberian vitamin A } \\
\text { pada balita }\end{array}$ & & & & \\
\hline & Pengetahuan ibu & $\begin{array}{lr}\text { Pegetahuan } & \text { ibu } \\
\text { balita } & \text { tentang } \\
\text { pentingnya } & \end{array}$ & Kuesioner & Ordinal & $\begin{array}{l}\text { 0. Kurang baik jika responden } \\
\text { mampu menjawab }<11 \\
\text { pertanyaan dengan benar }(<75 \%)\end{array}$ \\
\hline & & imunisasi vitamin A & & & $\begin{array}{l}1 \text { Baik, jika responden mampu } \\
\text { menjawab } 11-15 \text { pertanyaan } \\
\text { dengan benar }(76 \%-100 \%)\end{array}$ \\
\hline & Peran kader & $\begin{array}{lr}\text { Peran aktif } & \text { kader } \\
\text { posyandu } & \text { dalam } \\
\text { pemberian } & \text { vitamin } \\
\text { A }\end{array}$ & Kuesioner & Nominal & $\begin{array}{l}\text { 0. Kurang aktif, bila jawaban }< \\
\text { mean }(70,91) \\
\text { Aktif, bila jawaban } \geq \text { mean } \\
(70,91)\end{array}$ \\
\hline & $\begin{array}{l}\text { Keaktifan balita } \\
\text { dalam berkunjung } \\
\text { ke posyandu }\end{array}$ & $\begin{array}{l}\text { Kehadiran balita } \\
\text { dalam posyandu }\end{array}$ & Kuesioner & Nominal & $\begin{array}{l}\text { 0. Kurang aktif, bila jawaban }<40 \% \\
\text { 1. Aktif, bila jawaban } \geq 40 \%\end{array}$ \\
\hline
\end{tabular}




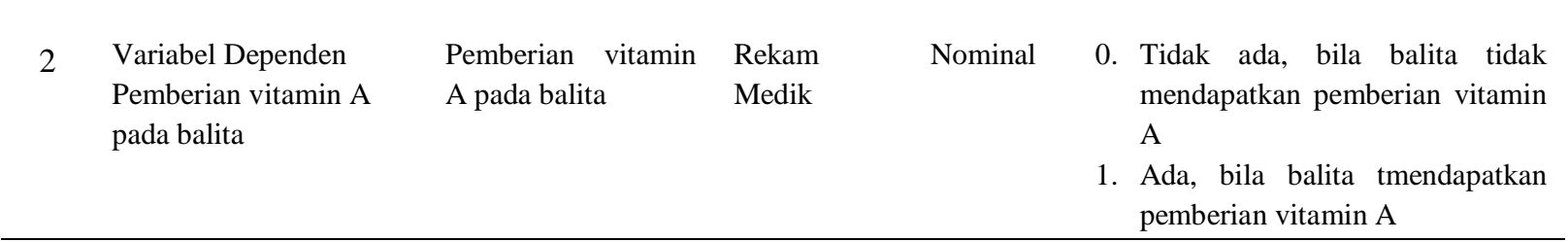

\section{H.Pengolahan Data}

Pengolahan data dilakukan dengan cara statistic menggunakan komputerisasi melalui langkah-langkah berikut :

1. Editing (Mengedit Data)

Setelah instrument penelitian (kuesioner) dikembalikan responden, maka setiap instrument akan diperiksa apakah sudah diisi dengan benar dan semua item sudah dijawab oleh responden.

2. Coding (Pengkodean)

Data yang sudah terkumpul diklarifikasikan dan diberi kode untuk masing-masing kelas dalam kategori yang sama.

3. Entry (Memasukkan Data)

Memasukkan data yang telah terkumpul kedalam computer untuk dianalisa dengan menggunakan komputer.

\section{Cleaning}

Memeriksa kembali data yang telah dimasukkan kedalam computer untuk memastikan bahwa data tersebut telah bersih dari kesalahan.

\section{Tabulating}

Memasukan data kedalam table berdasarkan variable dan kategori penelitian agar mudah dibaca.

\section{Analisa Data}

Analisis data dilakukan dengan menggunakan komputerisasi berupa Analisis Univariat dan Analisis Bivariat serta interprestasi data dalam bentuk table distribusi frekuensi.

\section{Analisis Univariat}

Analisis univariat untuk menjelaskan variable independen dan variable dependen. Analisis ini digunakan untuk menggambarkan distribusi frekuensi dari variable independen dan variable dependen. Analisis dilakukan secara deskriptif terhadap variable dan sub variabel, dengan menghitung distribusi frekuensi dan persentasikan dari tiaptiap variabel. Yang dilakukan dengan system komputerisasi.

Dengan Rumus:

$$
\mathbf{P}=\frac{f}{N} x 100 \%
$$

Keterangan :

$\mathrm{P}=$ Persentase

$\mathrm{f}=$ Frekuensi.

$\mathrm{N}=$ Jumlah seluruh observasi.

2. Analisis Bivariat

Analisis bivariat untuk melihat hubungan antara variable independen dan variable dependen, untuk melihat hubungan itu digunakan uji kemaknaan chi square $\left(\mathrm{X}^{2}\right)$, dengan tingkat kemaknaan $\mathrm{p}<0,05$. Untuk menyatakan berhubungan atau tidak berhubungan secara statistic dilihat dari nilai $p$-value yaitu bila $\mathrm{p} \leq 0,05$, Ho ditolak, artinya ada hubungan yang signifikan secara statistik, dan bila nilai $\mathrm{p}>0,05$, Ho gagal ditolak, artinya tidak ada hubungan yang signifikan secara statistic dan dilakukan dengan menggunakan system komputerisasi. 


$$
x^{2}=\frac{\Sigma(0-E)^{2}}{E}
$$

Keterangan :

$x^{2}=$ Chi Square

$0=$ Frekuensi observasi

$\mathrm{E}=$ Frekuensi yang diharapkan

(Hidayat, 2008)

Uji statistk yang digunakan adalah uji chi-square dengan batas derajat kepercayaan $\mathrm{p}<0,05$. Data diolah dengan menggunakan program komputer.
a. Jika hasil yang didapat $\mathrm{p}<0,05$ berarti hipotesa alternatif diterima
b. Jika hasil yang didapat $\mathrm{p}>0,05$ berarti hipotesa alternatif ditolak.

\section{BAB IV}

\section{HASIL PENELITIAN}

\section{A. Analisa Univariat}

Analisa Univariat dilakukan untuk melihat gambaran karakteristik masingmasing variabel yang meliputi : variabel dependen yaitu pemberian vitamin A pada balita, dan variabel independen yaitu pengetahuan ibu, peran kader, dan keaktifan kunjungan balita ke posyandu.

\begin{tabular}{l}
\hline Pendidikan Ibu \\
\hline Pendidikan rendah (SD-SMP) \\
Pendidikan menengah (SMA) \\
Pendidikan tinggi (PT) \\
Total \\
\hline Berdasarkan tabel 4.3 di atas dapat \\
dilihat bahwa distribusi frekuensi \\
pendidikan ibu balita di posyandu Desa \\
Beringin Lestari wilayah kerja Puskesmas \\
Tapung Hilir 1 yaitu 24 responden \\
(36,4\%) pendidikan tinggi. \\
Pekerjaan Ibu Puskesmas Tapung Hilir $\mathbf{1}$
\end{tabular}

1. Pemberian Vitamin A pada Balita

Tabel 4.1 Distribusi Frekuensi

Pemberian Vitamin A di posyandu Desa Beringin Lestari wilayah kerja

Puskesmas Tapung Hilir 1 Kabupaten Kampar Tahun 2018

\begin{tabular}{ccc}
\hline $\begin{array}{c}\text { Pemberian } \\
\text { Vitamin A }\end{array}$ & Frekuensi & Persentase (\%) \\
\hline Tidak ada & 19 & 28,8 \\
Ada & $\mathbf{4 7}$ & $\mathbf{7 1 , 2}$ \\
\hline Total & 66 & 100 \\
\hline
\end{tabular}

Berdasarkan tabel 4.1 di atas dapat dilihat bahwa sebahagian besar pemberian vitamin A di posyandu Desa Beringin Lestari wilayah kerja Puskesmas Tapung Hilir 1 sebanyak 47 responden $(71,2 \%)$ mendapatkan vitamin A.

\section{Pendidikan Ibu}

Tabel 4.3 Distribusi

Frekuensi

Pendidikan Ibu Balita di posyandu Desa Beringin Lestari wilayah kerja Puskesmas Tapung Hilir 1 Kabupaten Kampar Tahun 2018

\begin{tabular}{cc} 
rekuensi & Persentase $(\%)$ \\
\hline 23 & 34,8 \\
$\mathbf{1 9}$ & $\mathbf{2 8 , 8}$ \\
24 & 36,4 \\
66 & 100
\end{tabular}




\section{Pengetahuan Ibu}

Tabel 4.5 Distribusi

Frekuensi

Pengetahuan Ibu di posyandu

Desa Beringin Lestari wilayah kerja Puskesmas Tapung Hilir 1 Kabupaten Kampar Tahun 2018

\begin{tabular}{lcc}
\hline Pengetahuan Ibu & Jumlah & Persentase (\%) \\
\hline Kurang baik & 24 & 36,4 \\
Baik & $\mathbf{4 2}$ & $\mathbf{6 3 , 6}$ \\
\hline \multicolumn{1}{c}{ Total } & 66 & 100 \\
\hline
\end{tabular}

Berdasarkan tabel 4.5 dapat dilihat bahwa dari 66 responden di posyandu Desa Beringin Lestari wilayah kerja Puskesmas Tapung Hilir 1, ibu balita yang memiliki pengetahuan baik sebanyak 42 responden $(63,6 \%)$.

\section{Peran Kader}

Tabel 4.6 Distribusi Frekuensi Peran Kader di posyandu Desa Beringin Lestari wilayah kerja Puskesmas Tapung Hilir 1 Kabupaten Kampar Tahun 2018

\begin{tabular}{lcc}
\hline Peran kader & Jumlah & Persentase (\%) \\
\hline Kurang aktif & 33 & 50 \\
Aktif & 33 & 50 \\
\hline \multicolumn{1}{c}{ Total } & 66 & 100 \\
\hline
\end{tabular}

Berdasarkan tabel 4.6 dapat dilihat bahwa dari 66 responden di posyandu Desa Beringin Lestari wilayah kerja Puskesmas Tapung Hilir 1, yang menyatakan peran kader aktif sebanyak 33 responden $(50,0 \%)$.

\section{Keaktifan Balita dalam Berkunjung} ke Posyandu

Tabel 4.7 Distribusi Frekuensi Keaktifan Balita dalam Berkunjung ke Posyandu di posyandu Desa Beringin Lestari wilayah kerja Puskesmas Tapung Hilir 1 Kabupaten Kampar Tahun 2018

\begin{tabular}{lcc}
\hline $\begin{array}{c}\text { Keaktifan } \\
\text { balita }\end{array}$ & Jumlah & $\begin{array}{c}\text { Persentase } \\
(\%)\end{array}$ \\
\hline Kurang aktif & 22 & 33,3 \\
Aktif & 44 & 66,7 \\
\hline Total & 66 & 100 \\
\hline \multicolumn{3}{c}{ Berdasarkan tabel 4.7 dapat dilihat } \\
bahwa dari 66 & responden di posyandu \\
Desa Beringin & Lestari wilayah kerja \\
Puskesmas Tapung Hilir 1, yang balita aktif \\
berkunjung ke posyandu sebanyak 44 \\
responden (66,7\%).
\end{tabular}

\section{B. Analisis Bivariat}

\section{Hubungan Pengetahuan Ibu dengan} Pemberian Vitamin A pada Balita

Tabel 4.8 Hubungan Pengetahuan Ibu dengan Pemberian Vitamin A pada Balita di posyandu Desa Beringin Lestari wilayah kerja Puskesmas Tapung Hilir 1 Kabupaten Kampar Tahun 2018

\begin{tabular}{lcccccc}
\hline $\begin{array}{l}\text { Pengetahuan } \\
\text { ibu }\end{array}$ & \multicolumn{4}{c}{ Pemberian vitamin A } & \multirow{2}{*}{ Total } \\
\cline { 2 - 6 } & Tidak ada & \multicolumn{2}{c}{ Ada } & & \\
\cline { 2 - 6 } & $\mathbf{N}$ & $\mathbf{\%}$ & $\mathbf{N}$ & $\mathbf{\%}$ & $\mathbf{N}$ & $\mathbf{\%}$ \\
\hline Kurang baik & 12 & 50 & 12 & 50 & 24 & 100 \\
Baik & 7 & 16,7 & 35 & 83,3 & 42 & 100 \\
\hline Total & 19 & 28,8 & 47 & 71,2 & 66 & 100 \\
\hline \multicolumn{4}{c}{ Berdasarkan } & tabel & 4.8 & dapat \\
\end{tabular}

diketahui bahwa dari 24 responden ibu yang yang memiliki pengetahuan kurang, sebanyak 12 responden (50\%) balita yang mendapatkan vitamin A sebanyak 12 responden (50\%), dan sebaliknya dari 42 responden yang memiliki pengetahuan baik sebanyak 7 responden $(16,7 \%)$ tidak mendapatkan pemberian vitamin $\mathrm{A}$.

$$
\text { Hasil analisis uji statistik }
$$
diperoleh nilai $\mathrm{p}$ value $=0,009$ atau $\mathrm{p}<$ 0,05 , artinya ada hubungan yang signifikan antara pengetahuan ibu dengan pemberian vitamin A pada balita di posyandu Desa Beringin 
Lestari wilayah kerja Puskesmas Tapung Hilir 1. Serta didapatkan nilai $\mathrm{POR}=5,000$ dan $95 \% \mathrm{CI}=1,600-$ 15,628 yang artinya ibu balita yang memiliki pengetahuan kurang baik berpeluang 5,000 kali tidak mendapatkan pemberian vitamin A dibandingkan ibu balita yang memiliki pengetahuan baik.

\begin{tabular}{|c|c|c|c|c|c|c|c|c|}
\hline \multirow{3}{*}{$\begin{array}{l}\text { Peran } \\
\text { kader }\end{array}$} & \multicolumn{4}{|c|}{ Pemberian vitamin A } & \multirow{2}{*}{\multicolumn{2}{|c|}{ Total }} & \multirow{3}{*}{$\begin{array}{c}P \\
\text { Value }\end{array}$} & \multirow{3}{*}{$\begin{array}{c}\text { POR } \\
(95 \% \mathrm{CI})\end{array}$} \\
\hline & \multicolumn{2}{|c|}{ Tidak ada } & \multicolumn{2}{|c|}{ Ada } & & & & \\
\hline & $\mathbf{N}$ & $\%$ & $\mathbf{N}$ & $\%$ & $\mathbf{N}$ & $\%$ & & \\
\hline Kurang aktif & 17 & 51,5 & 16 & 48,5 & 33 & 100 & \multirow{3}{*}{0,000} & \multirow{3}{*}{$\begin{array}{c}16,469 \\
(3,377-80,317)\end{array}$} \\
\hline Aktif & 2 & 6,1 & 31 & 93,9 & 33 & 100 & & \\
\hline Total & 19 & 28,8 & 47 & 71,2 & 66 & 100 & & \\
\hline
\end{tabular}

Berdasarkan tabel 4.9 dapat diketahui bahwa 33 responden yang menyatakan peran kader kurang aktif sebanyak 16 responden $(48,5 \%)$ yang mendapatkan pemberian vitamin A. Sebaliknya dari 33 responden yang menyatakan peran kader aktif, 2 responden $(6,1 \%)$ tidak mendapatkan pemberian vitamin.

Hasil analisis uji statistik diperoleh nilai $\mathrm{p}$ value $=0,000$ atau $\mathrm{p}<0,05$, artinya ada hubungan yang signifikan antara peran kader dengan pemberian vitamin A pada balita di posyandu Desa Beringin Lestari wilayah kerja Puskesmas Tapung Hilir 1. Serta didapatkan nilai $\mathrm{OR}=16,469$ dan $95 \%$ $\mathrm{CI}=3,377-80,317$ yang artinya

\begin{tabular}{|c|c|c|c|c|c|c|c|c|}
\hline \multirow{3}{*}{$\begin{array}{c}\text { Keaktifan } \\
\text { balita }\end{array}$} & \multicolumn{4}{|c|}{ Pemberian vitamin A } & \multirow{2}{*}{\multicolumn{2}{|c|}{ Total }} & \multirow{3}{*}{$\begin{array}{c}P \\
\text { Value }\end{array}$} & \multirow{3}{*}{$\begin{array}{c}\text { POR } \\
(95 \% \mathrm{CI})\end{array}$} \\
\hline & \multicolumn{2}{|c|}{ Tidak ada } & \multicolumn{2}{|c|}{ Ada } & & & & \\
\hline & $\mathbf{N}$ & $\%$ & $\mathbf{N}$ & $\%$ & $\mathbf{N}$ & $\%$ & & \\
\hline Kurang aktif & 14 & 63,6 & 8 & 36,4 & 22 & 100 & \multirow{3}{*}{0,000} & \multirow{3}{*}{$\begin{array}{c}13,650 \\
(3,821-48,768)\end{array}$} \\
\hline Aktif & 5 & 11,4 & 39 & 88,6 & 44 & 100 & & \\
\hline Total & 19 & 28,8 & 47 & 71,2 & 66 & 100 & & \\
\hline
\end{tabular}

Berdasarkan tabel 4.10 dapat diketahui dari 22 responden dengan status kurang aktif balita dalam berkunjung ke posyandu yang
2. Hubungan Peran Kader dengan

Tabel 4.9 Hubungan Peran Kader dengan Pemberian Vitamin A pada Balita di posyandu Desa Beringin Lestari wilayah kerja Puskesmas Tapung Hilir 1 Kabupaten Kampar Tahun 2018

responden yang menyatakan peran kader kurang aktif berpeluang 16,469 kali tidak mendapatkan pemberian vitamin $\mathrm{A}$ dibandingkan responden yang menyatakan peran kader aktif.

\section{Hubungan Keaktifan Balita dalam} Berkunjung ke Posyandu dengan Pemberian Vitamin A pada Balita

Tabel 4.10 Hubungan Keaktifan Balita dalam Berkunjung ke Posyandu dengan Pemberian Vitamin A pada Balita di posyandu Desa Beringin Lestari wilayah kerja Puskesmas Tapung Hilir 1 Kabupaten Kampar Tahun 2018

mendapatkan pemberian vitamin A sebanyak 8 responden $(36,4 \%)$. Sedangkan dari 44 responden dengan status balita aktif berkunjung ke 
posyandu sebanyak 5 responden $(11,4 \%)$ tidak mendapatkan pemberian vitamin A.

Hasil analisis uji statistik diperoleh nilai $\mathrm{p}$ value $=0,000$ atau $\mathrm{p}<0,05$, artinya ada hubungan yang signifikan antara keaktifan balita dalam berkunjung ke posyandu dengan pemberian vitamin A pada balita di posyandu Desa Beringin Lestari wilayah kerja Puskesmas Tapung Hilir 1. Serta didapatkan nilai $\mathrm{OR}=$ 13,650 dan $95 \% \mathrm{CI}=3,821-48,768$ yang artinya balita yang kurang aktif dalam berkunjung ke posyandu berpeluang 13,650 kali tidak mendapatkan pemberian vitamin A dibandingkan balita yang berkunjung ke posyandu.

\section{BAB V}

\section{PEMBAHASAN}

\section{A. Pembahasan Hasil Penelitian}

\section{Hubungan Pengetahuan Ibu dengan Pemberian Vitamin A pada Balita}

Berdasarkan hasil penelitian dapat diketahui bahwa dari 24 responden ibu yang yang memiliki pengetahuan kurang, sebanyak 12 responden (50\%) balita yang mendapatkan vitamin A sebanyak 12 responden (50\%), dan sebaliknya dari 42 responden yang memiliki pengetahuan baik sebanyak 7 responden $(16,7 \%)$ tidak mendapatkan pemberian vitamin $\mathrm{A}$

Hasil analisis uji statistik diperoleh nilai $\mathrm{p}$ value $=0,015$ atau $\mathrm{p}<0,05$, artinya ada hubungan yang signifikan antara pengetahuan ibu dengan pemberian vitamin A pada balita di posyandu Desa Beringin Lestari wilayah kerja Puskesmas Tapung Hilir 1.

Menurut asumsi peneliti dari $12 \mathrm{ibu}$ yang balitanya mendapatkan vitamin A tetapi memiliki pengetahuan kurang baik kemungkinan disebabkan karena tingkat Ekonomi yang rendah. Asumsi peneliti dari 7 responden yang memiliki pengetahuan baik tetapi tidak mendapatkan pemberian vitamin A disebabkan karena faktor ibu balita yang bekerja sehingga tidak memiliki kesempatan untuk datang ke posyandu.

Penelitian ini sejalan dengan penelitian Indarwati (2015) yang berjudul Hubungan Tingkat Pengetahuan Ib sngan Cakupan Pemberian Vitamin A pada Balita di PKD Melati Sari Desa Durensari Kecamatan Bagelen Kabupaten Purworejo dimana adanya hubungan antara tingkat pengetahuan ibu dengan cakupan pemberian vitamin A pada balita ( $p$ value $=0,024)$ di PKD Melati Sari Desa Durensari Kecamatan Bagelen Kabupaten Purworejo.

Banyak faktor yang mempengaruhi tingkat pengetahuan seseorang. Pengetahuan adalah hasil tau yang berasal dari proses penginderaan manusia terhadap objek tertentu yang terjadi melalui panca indra yaitu melalui indra penglihatan, pendengaran, penciuman, rasa dan raba. Pengetahuan merupakan dasar yang paling penting dalam membentuk tindakan seseorang. Sebagian besar pengetahuan manusia diperoleh melalui mata dan telinga. Pengetahuan atau kognitif merupakan domain yang sangat penting dalam membentuk tindakan seseorang (overt behavior). Sedangkan faktor-faktor yang mempengaruhi pengetahuan seseorang antara lain: pendidikan, informasi, social budaya, pengalaman, social ekonomi (Notoatmodjo, 2007 ). Pengetahuan 
seseorang diperoleh dari pengalaman bermacam sumber, misalnya media massa, media elektronik, buku petunjuk, petugas kesehatan, media poster dan kerabat dekat. Pengetahuan sangat berhubungan erat dengan pendidikan, sedangkan pendidikan merupakan salah satu kebutuhan dasar manusia yang sangat diperlukan untuk menerima serta mengembangkan pengetahuan dan teknologi, sehingga semakin meningkatkan produktifitas dan kesejahteraan keluarga.

Jika ibu mengetahui manfaat dan pelayanan yang dilakukan diposyandu serta gunanya balita dibawa terusmenerus keposyandu dan arti pentingnya KMS sebagai alat untuk mencatat dan mengamati perkembangan kesehatan anak yang mudah dilakukan ibu, maka seorang ibu dapat menilai dan berbuat sesuatu untuk berusaha memperbaiki dan meningkatkan kesehatan anaknya. Hal ini sesuai dengan teori bahwa pengetahuan yang dimiliki seseorang merupakan dasar untuk berbuat, karena itu kemampuan seseorang melakukan sesuatu tergantung pengetahuan yang ia miliki. Atas dasar pengetahuan tentang posyandu, tujuan dan manfaat yang diperoleh di posyandu memungkinkan ibu untuk hadir pada setiap pelaksanaan posyandu.

\section{Hubungan Peran Kader dengan Pemberian Vitamin A pada Balita}

Berdasarkan hasil penelitian dapat diketahui bahwa 33 responden yang menyatakan peran kader kurang aktif sebanyak 16 responden $(48,5 \%)$ yang mendapatkan pemberian vitamin A. Sebaliknya dari 33 responden yang menyatakan peran kader aktif, 2 responden $(6,1 \%)$ tidak mendapatkan pemberian vitamin.

Hasil analisis uji statistik diperoleh nilai $\mathrm{p}$ value $=0,000$ atau $\mathrm{p}<0,05$, artinya ada hubungan yang signifikan antara peran kader dengan pemberian vitamin A pada balita di posyandu Desa Beringin Lestari wilayah kerja Puskesmas Tapung Hilir 1. Serta didapatkan nilai $\mathrm{OR}=16,469$ dan $95 \%$ $\mathrm{CI}=3,377-80,317$ yang artinya responden yang menyatakan peran kader kurang aktif berpeluang 16,469 kali tidak mendapatkan pemberian vitamin A dibandingkan responden yang menyatakan peran kader aktif.

Menurut asumsi peneliti dari 16 responden yang menyatakan oeran kader kurang aktif tetapi mendapatkan vitamin A karena pengetahuan ibu yang baik dan keaktifan balita dalam berkunjung ke posyandu, sehingga walaupun kader kurang aktif, responden tetap datang ke posyandu. Asumsi peneliti dari 2 responden yang menyatakan peran kader aktif tetapi tidak mendapatkan pemberian vitamin A disebabkan karena faktor ibu yang lalai dalam pemberian vitamin A kepada balitanya. Pada saat wawancara diketahui bahwa kader posyandu telah datang ke rumah responden untuk memberikan vitamin $\mathrm{A}$, tetapi ibu lalai memberikan vitamin kepada balitanya.

Penelitian ini sejalan dengan penelitian Puji Astuti (2013) yang berjudul Faktor-Faktor yang Berhubungan dengan Pemberian Vitamin A Pada Balita di Posyandu Dayu Makmur Sleman dimana adanya hubungan antara peran kader dengan pemberian vitamin A pada balita. 
Keaktifan kader sebagai pelaksana kegiatan posyandu merupakan kunci keberhasilan posyandu karena kader posyandu merupakan penghubung antara program dengan masyarakat serta memerlukan berbagai persyaratan tertentu agar keberadaannya diakui dan diterima masyarakat. Berlangsung dan tidaknya kegiatan di Posyandu tergantung dari kader, karena sebagian besar kegiatan di Posyandu dilakukakan oleh kader. Kader posyandu adalah anggota masyarakat yang bekerja secara sukarela, mampu melaksanakan UPGK dan mampu menggerakan masyarakat. Kader juga seorang ibu yang memiliki kemampuan yang berbeda-beda dalam melayani ibuibu yang memiliki balita, kemampuan ibu satu dengan ibu yang lainnya tentunya berbeda, untuk itu dari hasil ini juga menyebutkan beberapa ibu kurang baik dalam berperan sebagai kader. Kader yang bertugas memberi vitamin A di Posyandu biasanya juga tetangga sendiri di lingkungan tersebut, jadi ibu akan lebih mudah dan berani untuk meminta vitamin A atau memberikan masukan kepada kader apabila pelayanannya kurang sesuai.

Motivasi kader rendah atau kader menjadi jenuh dalam kegiatan posyandu maka bisa menyebakan kader drop out karena seperti yang kita ketahui bahwa menjadi kader merupakan pekerjaan sosial yang tidak mempunyai kekuatan mengikat jadi mereka leluasa untuk keluar menjadi kader apalagi ditambah regenerasi kader yang belum terencana dengan baik. Faktor lain yang menyebabkan kader tidak aktif adalah umur kader sudah lebih dari 50 tahun dan lama menjadi kader kurang dari 10 tahun sehingga posyandu dikelola oleh kader yang telah berpengalaman menjadi kader sekurangnya 60 bulan atau 5 tahun (Nain, 2008).

\section{Hubungan Keaktifan Balita dalam Berkunjung ke Posyandu dengan Pemberian Vitamin A pada Balita}

Berdasarkan hasil penelitian didapatkan bahwa dari 22 responden dengan status kurang aktif balita dalam berkunjung ke posyandu yang mendapatkan pemberian vitamin A sebanyak 8 responden $(36,4 \%)$. Sedangkan dari 44 responden dengan status balita aktif berkunjung ke posyandu sebanyak 5 responden $(11,4 \%)$ tidak mendapatkan pemberian vitamin A.

Hasil analisis uji statistik diperoleh nilai $\mathrm{p}$ value $=0,000$ atau $\mathrm{p}<0,05$, artinya ada hubungan yang signifikan antara keaktifan balita dalam berkunjung ke posyandu dengan pemberian vitamin A pada balita di posyandu Desa Beringin Lestari wilayah kerja Puskesmas Tapung Hilir 1. Serta didapatkan nilai $\mathrm{OR}=$ 13,650 dan $95 \% \mathrm{CI}=3,821-48,768$ yang artinya balita yang kurang aktif dalam berkunjung ke posyandu berpeluang 13,650 kali tidak mendapatkan pemberian vitamin A dibandingkan balita yang berkunjung ke posyandu.

Menurut asumsi peneliti dari 8 responden yang balitanya kurang aktif berkunjung ke posyandu tetapi mendapatkan vitamin A kemungkinan disebabkan karena pengetahuan ibu yang baik dan pekerjaan ibu yang sibuk, sehingga walaupun balita kurang aktif ke posyandu, ketika kader datang ke rumah untuk memberikan vitamin A, balita tetap mendapatkan vitamin A. 
Asumsi peneliti dari 5 responden yang balita yang aktif berkunjung ke posyandu tetapi tidak mendapatkan pemberian vitamin A disebabkan karena pada saat bulan vitamin A (Februafi dan Agustus) balita tidak berkunjung ke posyandu.

Penelitian ini sejalan dengan penelitian Puji Astuti (2013) yang berjudul Faktor-Faktor yang Berhubungan dengan Pemberian Vitamin A Pada Balita di Posyandu Dayu Makmur Sleman dimana terdapat hubungan yang signifikan antara keaktifan balita dalam berkunjung ke posyandu dengan pemberian vitamin $\mathrm{A}$ pada balita.

Kunjungan balita ke posyandu adalah datangnya balita ke posyandu untuk mendapatkan pelayanan kesehatan misalnya penimbangan, imunisasi, penyuluhan gizi dan lain sebagainya. Kunjungan balita ke posyandu yang paling baik adalah teratur setiap bulan atau 12 kali per tahun. Untuk ini kunjungan balita diberikan batasan 8 kali per tahun. Posyandu yang frekuensi penimbangan atau kunjungan balitanya kurang dari 8 kali per tahun di anggap masih rawan. Sedangkan bila frekuensi penimbangan sudah lebih 8 kali atau lebih dalam kurun waktu satu tahun dianggap sudah cukup baik,tetapi frekuensi penimbangan tergantung dari jenis posyandu (Puji Astuti, 2013).

\section{DAFTAR PUSTAKA}

Arisman, MB (2010). Buku Ajar Ilmu Gizi: Gizi Dalam Baur Kehidupan Edisi 2. Jakarta : ECG

Cahyaningrum, dkk. (2017). Hubungan Tingkat Pengetahuan Ibu Tentang
Vitamin A Dengan Kepatuhan Ibu Memberikan Kapsul Vitamin A Pada Balita Usia 12 - 59 Bulan Di Wilayah Kerja Puskesmas Rowosari Kota Semarang. AKBID Abdi Husada Semarang

Dinkes Prov Riau (2015). Profil Dinas Kesehatan Provinsi Riau Tahun 2015. Riau

Dwiana Putri. (2014). Hubungan Tingkat Pengetahuan Ibu dengan Upaya Kepatuhan Pemberian Vitamin A Pada Balita di Puskesmas Wirobrajan Yogyakarta Tahun 2014. STIKes Aisyiyah Yogyakarta

Indarwati (2015). Hubungan Antara Tingkat Pengetahuan Ibu dengan Cakupan Pemberian Vitamin A Pada Balita di PKD Melati Sari Desa Durensari Kecamatan Bagelen Kabupaten Purworejo. Skripsi

Kemenkes (2013). Buku Panduan Kader Posyandu. Jakarta : Kemenkes RI

(2015). Pedoman Gizi Seimbang. Jakarta : Kemenkes RI

(2016). Panduan Penggunaan Aplikasi PMKDR Distribusi Kapsul Vitamin A. Jakarta : Kemenkes RI

(2017). Profil Kesehatan Indonesia. Jakarta : Kemenkes RI

Mansur (2009). Kapita Selecta Kedokteran. Jilid 1 Edisi 3 Jakarta : EGC

Nain, U. (2008). Posyandu : Upaya Kesehatan Berbasis Masyarakat, Kareso: Yogyakarta.

Notoatmodjo, S. (2007). Promosi Kesehatan Ilmu Perilaku. Jakarta : Rineka Cipta (2010). Metodelogi Penelitian. Jakarta : Rineka Cipta

Puji Astuti. (2013). Faktor-Faktor yang Berhubungan dengan Pemberian Vitamin A Pada Balita di Posyandu 
Dayu Makmur Sleman. STIKes Jendral Ahmad Yani Yogyakarta

Sediaoetama (2009). Ilmu Gizi II. Jakarta : PT

Dian Rakyat

Sulistyoningsih, H. (2011). Gizi Untuk Kesehatan Ibu dan Anak. Yogyakarta: PT Graha Ilmu

Sunita almatsier (2009). Prinsip Dasar Ilmu

Gizi. Jakarta : PT Gramedia Pustaka Utama

Tim Penyusun. (2018). Buku Panduan Penulisan Karya Tulis Ilmiah Mahasiswa. Bangkinang: Universitas Pahlawan Tuanku Tambusai Bangkinang Riau 